\title{
Effects of arbuscular mycorrhizal fungi on caesium accumulation and the ascorbate-glutathione cycle of Sorghum halepense
}

\author{
Ren-Hua Huang ${ }^{\mathrm{a}, \mathrm{b}}$, Yun-Mei Lu ${ }^{\mathrm{b}}$, Hui-Ling Yang ${ }^{\mathrm{a}, \mathrm{b}}$, Wei Huang ${ }^{\mathrm{a}, \mathrm{b}}$, Ke Chen $^{\mathrm{a}, *}$ \\ a Fundamental Science on Nuclear Wastes and Environmental Safety Laboratory, \\ Southwest University of Science and Technology, Mianyang, Sichuan 621010, China \\ b College of Life Science and Engineering, Southwest University of Science and Technology, Mianyang, \\ Sichuan 621010, China
}

*Corresponding author, e-mail: huangrenhua@swust.edu.cn

Received 27 Aug 2014

Accepted 30 Oct 2016

\begin{abstract}
A pot experiment was conducted to study the effects of Glomus mosseae and Glomus versiforme on the ascorbate-glutathione cycle metabolism and caesium enrichment in roots and leaves of Sorghum halepense. The results showed that inoculated G. mosseae and G. versiforme significantly increased the concentrations of ascorbate (AsA) and reduced glutathione (GSH), the ratios of AsA/DHA (dehydroascorbate) and GSH/GSSG (oxidized glutathione) in roots and leaves of $S$. halepense in Cs contaminated soil. Additionally, the inoculated arbuscular mycorrhizal fungi increased the antioxidant enzyme activities of the ascorbate-glutathione cycle, with the best efficiency provided by G. mosseae. The activities of antioxidant enzymes (ascorbate peroxidase, APX, EC 1.11.1.11; dehydroascorbate reductase, DHAR, EC 1.8.5.1; and glutathione reductase, glutathione reductase (GR), EC 1.8.1.7) in the roots were, respectively, 4.7, 3.6, and 2.3 times higher than those in non-inoculated roots, and the activities of DHAR was 1.7 times higher than that in non-inoculated leaves. However, G. versiforme increased the activity of monodehydroascorbate reductase (MDHAR, EC 1.6.5.4) 2.39 U/g fresh weight, and the activities of APX and GR were 6.8 and 1.4 times higher than for nonmycorrhizal plants. G. versiforme also increased the accumulation of caesium in roots and leaves but to a lesser extent than G. mosseae, and with a positive effect on translocation. Thus arbuscular mycorrhizal fungi promotes efficient operation of ascorbate-glutathione cycle in the roots and leaves of $S$. halepense, enhancing its tolerance to Cs stress.
\end{abstract}

KEYWORDS: bioremediation, phytoremediation, Johnson grass, Cs stress

\section{INTRODUCTION}

Environmental pollution by radiocaesium $\left({ }^{134} \mathrm{Cs}\right.$ and ${ }^{137} \mathrm{Cs}$ ) results from nuclear installations and above-ground testing of thermo-nuclear weapons, thereby the soil becomes the world major reser$\operatorname{voir}^{1,2}$. Due to the low mobility of radiocaesium in soils, this radio-pollutant mainly accumulates in the topsoil ${ }^{3}$; as a consequence, one of the principal routes for radiocaesium entry into the food chain is by means of soil-to-plant ${ }^{4}$, becoming a serious hazard for human health ${ }^{5,6}$. To limit caesium dispersion in the environment, various remedial actions including mineral amendments, $\mathrm{K}$ fertilization agricultural-based countermeasures ${ }^{7}$, and chemical and bioindicator methods ${ }^{8}$ have been proposed. Of them, phytoremediation was regarded as the most compatible method for long-term bioremediation of radiocaesium contaminated soils, because it is not destructive for the environment ${ }^{9}$. The plants used for bioremediation however do not grow well or even die in environments contaminated with lowlevel of radionuclides, which destroys the rhizosphere microenvironment of the plants ${ }^{10,11}$. Thus a combination of the plants and microorganisms with mutual benefits has been proposed recently to remove or immobilize radiocaesium ${ }^{12,13}$.

The arbuscular mycorrhizal fungi (AMF) are universal soil microbes constituting an integral component of terrestrial ecosystems, forming symbiotic associations with plant root systems of over $80 \%$ of all terrestrial plant species, including most angiosperms, some gymnosperms, pteridophytes, lycopods, and mosses ${ }^{14,15}$. AMF are involved in the most widely distributed root symbioses among the soil microflora, forming associations with most ter- 
restrial flowering plants ${ }^{16}$, improving their growth conditions, and alleviating toxicity of environmental stresses such as diesel contamination ${ }^{17}$. AMF are developed inside roots and within the soil by forming extensive extraradical mycelium nets which help the plant to extract mineral nutrients and water from the soil. AMF have been introduced into phytoremediation of soil contaminated with radionuclides to enhance plat resistance and capacity to accumulate radionuclides. Declerck et al demonstrated that the extraradical hyphal network of AMF incorporate and translocate radiocaesium from a radiocaesium labelled root-free compartment to a root compartment, using a monoxenic multicompartment growing system ${ }^{18}$. De Boulois et al suggested that there was the possibility, although limited, of radiocaesium accumulation in the intraradical mycelium ${ }^{19}$. Chen et al also reported that AMF raised the biomass of Pteris vittata, significantly, when increased $U$ concentrations in the root, and had a high transfer factor value, indicating that the intraradical hyphae may take advantage of microorganisms and rhizosphere microenvironment to transform radionuclides in soil effectively ${ }^{20}$. Additionally, it has been reported that intraradical fungal structures of Glomus lamellosum can induce the down-regulation of radiocaesium channels involved in the transport processes of radiocaesium towards the xylem ${ }^{13}$.

The ascorbate-glutathione cycle has an important function in alleviating damage of plants under stress. The ascorbate (AsA) is the most abundant antioxidant in plants and plays a role in the response to oxidative stress. It has been shown that exogenous application of ascorbate increases resistance to chilling, drought, and salt stresses ${ }^{21,22}$. Simultaneously, reduced glutathione (GSH) is central to the regeneration of ascorbic acid in the ascorbateglutathione cycle and is used as a potential marker for oxidative changes in plant metabolism. The antioxidant enzymes including ascorbate peroxidase (APX, EC 1.11.1.11), monodehydroascorbate reductase (MDHAR, EC 1.6.5.4), dehydroascorbate reductase (DHAR, EC 1.8.5.1), and glutathione reductase (GR, EC 1.8.1.7) constitute ascorbateglutathione cycle. The present study showed that the four participating enzymes increased more than the control after 70 days experimental free-air ozone exposure $^{23,24}$. This study aimed to evaluate the effects of AMF (G. mosseae and G. versiforme) on ascorbate-glutathione cycle of Sorghum halepense on alleviating caesium stress in soil. The findings would have important implications in revealing the mechanisms that confer stress resistance and provide insights into the potential of $S$. halepense to adapt to environmental stress.

\section{MATERIALS AND METHODS}

\section{The soil contaminated with Cs treatments}

The soils used for experiments were from Southwest University of Science and Technology (SWUST) garden. To prepare the soils, they were mixed with clean river sands $(7: 1, \mathrm{v} / \mathrm{v})$ after removing grassroots. Those mixtures had $\mathrm{pH} 5.81,1.84 \mathrm{~g} / \mathrm{kg}$ of total nitrogen, $10.62 \mathrm{mg} / \mathrm{kg}$ of effective phosphorus, $25.65 \mathrm{mg} / \mathrm{kg}$ of effective potassium $25 \%$ of water moisture capacity, and $8.4 \mathrm{~g} / \mathrm{kg}$ of organic matter content. Before the experiments the soils were autoclaved $24 \mathrm{~h}$ and kept in the dark for a week, and then $8.0 \mathrm{~kg}$ of the mixture, $0.1 \mathrm{~g}$ of fertilizers $\left(\mathrm{NH}_{4}\right)_{2} \mathrm{SO}_{4}$, and $0.05 \mathrm{~g}$ of $\mathrm{KH}_{2} \mathrm{PO}_{4}$ were added into each pot at seeding time with addition of water to keep the moisture saturated for two weeks. Then, $20 \mathrm{mg} / \mathrm{kg}$ of $\mathrm{CsCl}$ solution, which was prepared considering two factors: plant growth condition and soil condition contaminated with $\mathrm{CsCl}$ determined according to the $\mathrm{CsCl}$ gradient experiment, was added to each pot. At the second day of the experiment, water was added to keep water-holding capacity from $70 \%$ to $80 \%$. The soils were kept in wet conditions with regular addition of water to maintain the moisture capacity. Cs concentrations in the surface and underlying of soil were measured weekly. There was no significant difference of Cs concentrations between the surface and underlying of soil after 4 weeks.

\section{Experimental strain culture}

Four weeks later, G. mosseae and G. versiforme used in the experiment consisted of root segment of the host plant, the corresponding mycorrhizal fungi spore, and rhizosphere soil of mycelium out of roots. Seeds of subterranean clover (Trifolium subterraneum) were surface-sterilized by immersing in $2 \mathrm{M}$ $\mathrm{H}_{2} \mathrm{O}_{2}$ for $10 \mathrm{~min}$, rinsed in deionized water and germinated on wet tissue for $48 \mathrm{~h}$ before sowing. The source of inoculum was an air-dried and sieved $(\leqslant 2 \mathrm{~mm})$ soil collected from 4 month-old pure culture pots of subterranean clover inoculated with the mixture of $G$. mosseae and $G$. versiforme.

\section{Experimental phase}

From each of the same size plastic pots, $6.0 \mathrm{~kg}$ of mixtures were collected. For mycorrhizal treatments $\left(+\mathrm{Cs}^{+G \text {. mosseae }}\right.$ and $\left.+\mathrm{Cs}^{+G \text {. versiforme }}\right)$ a portion 
of $200 \mathrm{~g}$ of soil mixture was added into $50 \mathrm{~g}$ of inoculum and nonmycorrhizal $\left(+\mathrm{Cs}^{-\mathrm{AM}}\right.$ and $-\mathrm{Cs}^{-\mathrm{AM}}$ ) as control. Meanwhile, S. halepense seeds were sterilized with $10 \% \mathrm{H}_{2} \mathrm{O}_{2}$ for $10 \mathrm{~min}$, rinsed with distilled water for several times, and germinated at $25^{\circ} \mathrm{C}$ for 3 days, $8-10$ seeds placed onto per pot, and then covered using the remained soil. In the 10 groups of control pots, the same sterilized inoculum and treatment were used as monoclonal village. To obtain the $70-80 \%$ of water moisture capacity, routine water was provided. The plants were maintained in the greenhouse with $16 / 8 \mathrm{~h}$ light/dark cycles, varying temperature between a minimum of $15^{\circ} \mathrm{C}$ during the night and a maximum of $29^{\circ} \mathrm{C}$ on sunny days, and maintaining the humidity between 70 and $80 \%$. The light intensity was in the range $438-1880 \mu \mathrm{mol} \mathrm{m} \mathrm{m}^{-2} \mathrm{~s}^{-1}$ photon flux density and the minimum was supplied by Philips SON-T 400 daylight lamps (380-779 nm) with an automatic regulation, while the daily maxima were reached on sunny days. Plants were watered daily by weight. After 4 weeks, root samples were taken from pots and analysed for AMF colonization as described below. All tests were done in the new glass greenhouse of Southwest University of Science and Technology.

\section{Determination of mycorrhizal colonization rate}

Roots were used to estimate mycorrhizal colonization rate as described by Phillips and Hayman method $^{25}$. They were carefully washed, cut into 1$\mathrm{cm}$ root segment, fixed with FAA fixative liquid for at least $24 \mathrm{~h}$, and then incubated in $10 \% \mathrm{KOH}$ for $1.5-$ $2 \mathrm{~h}$ at $90^{\circ} \mathrm{C}$. Subsequently, after carefully washing with distilled water, the roots were bleached in 10\% $\mathrm{H}_{2} \mathrm{O}_{2}$ for 10-15 min, acidified for $1 \mathrm{~h}$ (or overnight) in $0.2 \mathrm{M} \mathrm{HCl}$. Then the roots were washed carefully four times with distilled water, and immediately added into a trypan blue-lactic acid phenol solution and dyed for $5 \mathrm{~min}$. To examine the colonies, the root segments were placed on a glass slide coated with mounting medium and covered with cover glass to look at AMF colonization under XSZ-3G biological microscope. The frequency of occurrence of AMF colonization (\%) was calculated as the percentage of root segments colonized by hyphae, arbuscular or vesicles/the length of examined root segment.

\section{Determination of AsA and DHA}

Five grams of plant root and leaf (FW) were homogenized in $5 \mathrm{ml}$ of $5 \%(\mathrm{w} / \mathrm{v})$ trichloroacetic acid (TCA). The homogenate was filtered through four layers of Miracloth and centrifuged for $10 \mathrm{~min}$ at $16000 \mathrm{~g}\left(4^{\circ} \mathrm{C}\right)$. The supernatant was used for assay of AsA and total ascorbate. AsA and DHA were determined using the method described by Chen and Wang ${ }^{26}$. The AsA assay mixture containing of $0.2 \mathrm{ml}$ of the supernatant, $0.5 \mathrm{ml} 100 \mathrm{mM}$ phosphate buffer (pH 7.7), $0.4 \mathrm{ml} 10 \%$ TCA, $0.4 \mathrm{ml} \mathrm{44 \%}$ phosphoric acid, $0.4 \mathrm{ml} 4 \%$ 2,2-bipyridyl, and $0.2 \mathrm{ml}$ $3 \%$ ferric trichloride, was incubated for $60 \mathrm{~min}$ at $37^{\circ} \mathrm{C}$ and then cooled down to room temperature. Absorbance of the coloured solution was recorded at $525 \mathrm{~nm}$. The total ascorbate (AsA+DHA) assay mixture, $0.2 \mathrm{ml}$ supernatant, $0.25 \mathrm{ml} 100 \mathrm{mM}$ phosphate buffer (pH 7.7) and $0.25 \mathrm{ml} 0.2 \mathrm{mM}$ dithiothreitol, was kept for $10 \mathrm{~min}$ at room temperature, followed by addition of $0.4 \mathrm{ml}$ TCA (10\%), $0.4 \mathrm{ml}$ phosphoric acid (44\%), $0.4 \mathrm{ml} \mathrm{4 \%} \mathrm{2,2-bipyridyl,}$ and $0.2 \mathrm{ml} 3 \%$ ferric trichloride. The final mixture was incubated for $60 \mathrm{~min}$ at $37^{\circ} \mathrm{C}$ before absorbance at $525 \mathrm{~nm}$ was recorded. Dehydroascorbate concentration was estimated from the difference of 'total ascorbate' and 'ascorbate' concentrations. A standard curve in the range $0-10 \mathrm{mM}$ of ascorbate was used.

\section{Measurement of GSH and GSSG}

Five grams of plant root and leaf (FW) were homogenized in $5.0 \mathrm{ml}$ ice-cold $60.0 \mathrm{mM}$ phosphate solution with a chilled mortar and pestle under $\mathrm{N}_{2}$ at $0{ }^{\circ} \mathrm{C}$. The homogenate was centrifuged for $15 \mathrm{~min}$ at $20000 \mathrm{~g}\left(4^{\circ} \mathrm{C}\right)$ and the supernatant was subjected to GSH and GSSG measurement as described by Ref. 27. Total GSH equivalents were determined by reacting $0.3 \mathrm{ml}$ supernatant, $0.5 \mathrm{ml}$ of extract with $60 \mathrm{mM} \mathrm{KH}_{2} \mathrm{PO}_{4}-2.5 \mathrm{mM}$ EDTA buffer (pH 7.7), $0.2 \mathrm{ml} 0.6 \mathrm{mM}$ 5,5-dithiobis (2-nitrobenzoic acid) (DTNB) in $200 \mathrm{mM}$ Tris-HCl (pH 8.0), $1 \mathrm{ml} 1 \mathrm{U}$ of GR (from Sigma, EC 1.6.4.2) and $1 \mathrm{ml} 0.2 \mathrm{mM}$ NADPH. The reaction was followed as the rate of change in absorbance at $412 \mathrm{~nm}$, and the total glutathione concentration was calculated from a standard curve. GSSG was determined after removal of GSH from the sample extract. GSH was determined from the reaction mixture by mixing $0.3 \mathrm{ml}$ supernatant, $0.5 \mathrm{ml}$ of extract with $60 \mathrm{mM} \mathrm{KH}{ }_{2} \mathrm{PO}_{4}-2.5 \mathrm{mM}$ EDTA buffer (pH 7.7) and $0.2 \mathrm{ml} 0.6 \mathrm{mM}$ DTNB in $200 \mathrm{mM}$ Tris- $\mathrm{HCl}$ (pH8.0). The mixture was incubated at $30^{\circ} \mathrm{C}$ for $10 \mathrm{~min}$, and the reaction was followed as the rate of change in absorbance at $412 \mathrm{~nm}$. The GSSG concentration was estimated from the difference of 'total glutathione' and 'glutathione' concentrations. A standard curve in the range 0$10 \mathrm{mM}$ GSH was used. 


\section{Determination of APX, MDHAR, DHAR and GR}

Samples of fresh plant roots and leaves $(5.0 \mathrm{~g})$ were homogenized in $3.5 \mathrm{ml} 50 \mathrm{mM}$ ice-cold $\mathrm{K}_{3} \mathrm{PO}_{4}$ (pH 7.6), containing $1.0 \mathrm{mM}$ EDTA, $1.0 \mathrm{mM}$ sodium ascorbate and $4 \%$ polyvinylpyrrolidone. After grinding, $1.5 \mathrm{ml}$ saturated $\left(\mathrm{NH}_{4}\right)_{2} \mathrm{SO}_{4}$ was added. The homogenate was centrifuged for $20 \mathrm{~min}$ at $15000 \mathrm{~g}$ $\left(4^{\circ} \mathrm{C}\right)$, and the supernatant was used for the enzyme assays according to Krivosheeva et al with slight modifications ${ }^{28}$.

For the APX assay, the reaction mixture contained $0.8 \mathrm{ml}$ of $0.5 \mathrm{mM}$ ascorbate, $0.1 \mathrm{ml}$ of $2.0 \mathrm{mM} \mathrm{H}_{2} \mathrm{O}_{2}$ (both were made fresh) and $0.1 \mathrm{ml}$ supernatant. The decrease in absorbance at $290 \mathrm{~nm}$ (ascorbate consumption) was recorded for the first three minutes after the reaction had started by adding the enzyme extract (extinction coefficient was $2.8 \mathrm{mM} / \mathrm{cm}$ ).

For the MDHAR assay, the reaction mixture contained $0.83 \mathrm{ml}$ of $2 \mathrm{mM}$ ascorbate, $0.05 \mathrm{ml} 2 \mathrm{mM}$ $\mathrm{NADPH}, 0.02 \mathrm{ml}$ ascorbate oxidase (two units) and $0.1 \mathrm{ml}$ supernatant. The formation of ascorbate was recorded as the increase of absorbance at $292 \mathrm{~nm}$ (extinction coefficient of $6.2 \mathrm{mM} / \mathrm{cm}$ ).

For the DHAR assay, the reaction mixture contained $0.7 \mathrm{ml} 50 \mathrm{mM}$ EDTA, $0.1 \mathrm{ml} 2 \mathrm{mM}$ dehydroascorbate (DHA), $0.1 \mathrm{ml}$ of $25 \mathrm{mM} \mathrm{GSH}$ and $0.1 \mathrm{ml}$ enzyme extract. The increment of absorbance was determined at $265 \mathrm{~nm}$ (extinction coefficient of $14 \mathrm{mM} / \mathrm{cm}$ ).

For the GR assay, the reaction mixture contained $0.82 \mathrm{ml} 1 \mathrm{mM}$ GSSG $0.08 \mathrm{ml}$ of $2.0 \mathrm{mM}$ NADPH and $0.1 \mathrm{ml}$ supernatant. The consumption of NADPH was followed as the decrease in absorbance at $340 \mathrm{~nm}$ during the first three minutes of the reaction (extinction coefficient of $6.2 \mathrm{mM} / \mathrm{cm}$ ).

The specific enzyme activity for all the above enzymes was expressed on the basis of fresh weight.

\section{Statistical analysis}

Data were analysed using SAS SYSTEM for Windows 9.1. The data were subjected to combined ANOVA and the means that were significantly different were separated at $p<0.05$ by the least significant difference test. Mean values were compared using Duncan's multiple range test.

\section{RESULTS}

\section{Mycorrhizal colonization rate}

The mycorrhizal colonization rate of $G$. mosseae and $G$. versiforme was $52 \%$ and $61 \%$, respectively

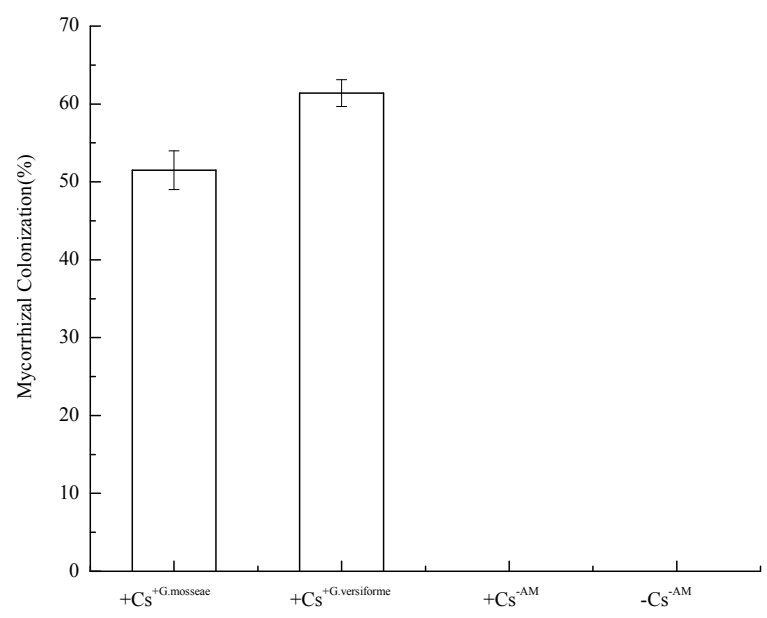

Fig. 1 Mycorrhizal colonization rate in roots of $+\mathrm{Cs}^{+ \text {G. mosseae }},+\mathrm{Cs}^{+ \text {G. versiforme }},+\mathrm{Cs}^{-\mathrm{AM}}$, and $-\mathrm{Cs}^{-\mathrm{AM}}$ in $S$. halepense. In this Figure and the following, each value is the mean of three replicates \pm standard error, $n=3$.

(Fig. 1). The control ( $+\mathrm{Cs}^{-\mathrm{AM}}$ and $\left.-\mathrm{Cs}^{-\mathrm{AM}}\right)$ had no signs of colonization.

\section{Effects of AMF on non-enzymes in the ascorbate-glutathione cycle}

Table 1 shows the effects of AMF on ascorbate pool in leaves and roots. The concentrations of AsA in the root and leaf of $S$. halepense with $+\mathrm{Cs}^{+G}$. versiforme plants were approximately 1.65 - and 7.02-fold higher than in $+\mathrm{Cs}^{-\mathrm{AM}}$ plants, respectively. But, there was no difference between $+\mathrm{Cs}^{-\mathrm{AM}}$ and $-\mathrm{Cs}^{-\mathrm{AM}}$ plants. Meanwhile, the concentrations of DHA of $+\mathrm{Cs}^{+ \text {G. mosseae }}$ plants were $21 \%, 36 \%$ lower than $+\mathrm{Cs}^{-\mathrm{AM}}$ in the leaf and the root. For $+\mathrm{Cs}^{+G \text {. versiforme }}$, there was a significant difference in relative to $+\mathrm{Cs}^{-\mathrm{AM}}$ in leaf, but not in the roots. In addition, the AsA/DHA ratios of $+\mathrm{Cs}^{+G}$. mosseae and $+\mathrm{Cs}^{+G \text {. versiforme }}$ plants were about 6.42 - and 15.75 fold higher than $+\mathrm{Cs}^{-\mathrm{AM}}$ plants in the leaves, respectively. In roots, AsA/DHA ratios of $+\mathrm{Cs}^{+G}$. mosseae and

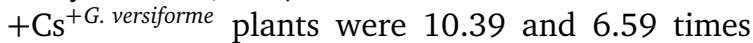
significantly higher than $+\mathrm{Cs}^{-\mathrm{AM}}$ plant, respectively.

The effects of AMF on GSH concentrations of leaves and roots exposed to Cs are shown in Table 2. The GSH concentrations of $+\mathrm{Cs}^{+G}$. mosseae

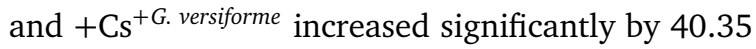
and $53.43 \mathrm{ng} / \mathrm{gFW}$, respectively, compared to those of $+\mathrm{Cs}^{-\mathrm{AM}}$ in the roots, while GSH concentrations of $+\mathrm{Cs}^{+G \text {. mosseae }}$ and $+\mathrm{Cs}^{+G \text {. versiforme }}$ decreased significantly by 92.14 and $131.4 \mathrm{ng} / \mathrm{gFW}$ compared to $+\mathrm{Cs}^{-\mathrm{AM}}$ in leaves. The GSSG concentrations of $+\mathrm{Cs}^{+G}$ mosseae was less pronounced com- 
Table 1 The effects of different arbuscular mycorrhizal fungi on ascorbate, dehydroascorbate concentration and the ratios of them in roots and leaves in $S$. halepense.

\begin{tabular}{|c|c|c|c|c|c|c|}
\hline \multirow[t]{2}{*}{ Treatments $^{\dagger}$} & \multicolumn{2}{|c|}{ AsA $(\mu \mathrm{g} / g F W)^{*}$} & \multicolumn{2}{|c|}{ DHA $(\mu g / g F W)$} & \multicolumn{2}{|c|}{ AsA/DHA } \\
\hline & Root & Leaf & Root & Leaf & Root & Leaf \\
\hline$+\mathrm{Cs}^{+ \text {G. mosseae }}$ & $1.26 \pm 0.02^{\mathrm{b}}$ & $0.98 \pm 0.04^{b}$ & $0.05 \pm 0.01^{\mathrm{c}}$ & $0.06 \pm 0.01^{\mathrm{b}}$ & $24.7 \pm 2.7^{\mathrm{a}}$ & $17.3 \pm 1.0^{\mathrm{b}}$ \\
\hline$+\mathrm{Cs}^{+G . \text { versiforme }}$ & $2.81 \pm 0.02^{\mathrm{a}}$ & $1.49 \pm 0.04^{\mathrm{a}}$ & $0.18 \pm 0.01^{\mathrm{b}}$ & $0.04 \pm 0.01^{\mathrm{b}}$ & $15.7 \pm 1.1^{\mathrm{b}}$ & $42.4 \pm 7.5^{\mathrm{a}}$ \\
\hline$+\mathrm{Cs}^{-\mathrm{AM}}$ & $0.43 \pm 0.03^{c}$ & $0.90 \pm 0.03^{\mathrm{b}}$ & $0.19 \pm 0.04^{b}$ & $0.34 \pm 0.04^{\mathrm{a}}$ & $2.38 \pm 0.09^{c}$ & $2.69 \pm 0.31^{\mathrm{b}}$ \\
\hline$-\mathrm{Cs}^{-\mathrm{AM}}$ & $0.40 \pm 0.01^{\mathrm{c}}$ & $0.85 \pm 0.02^{\mathrm{b}}$ & $0.26 \pm 0.05^{\mathrm{a}}$ & $0.45 \pm 0.05^{\mathrm{a}}$ & $1.51 \pm 0.01^{\mathrm{c}}$ & $1.93 \pm 0.25^{\mathrm{b}}$ \\
\hline
\end{tabular}

$\dagger+\mathrm{Cs}^{+G \text {. mosseae }}$ : inoculation with G. mosseae under Cs stress; $+\mathrm{Cs}^{+ \text {G. versiforme }}$ : inoculation with G. versiforme under Cs stress; $+\mathrm{Cs}^{-\mathrm{AM}}$ : non-inoculation treatments under Cs stress; $-\mathrm{Cs}^{-\mathrm{AM}}$ : non-inoculation treatments without Cs stress.

$\star$ In this Table and the following, each value is the mean of three replicates $\pm \mathrm{SE}$ across rows and columns; lowercase letters in each column mean significant difference.

Table 2 The effects of different arbuscular mycorrhizal fungi on reduced glutathione, oxidized glutathione concentration and the ratios of them in roots and leaves in $S$. halepense.

\begin{tabular}{|c|c|c|c|c|c|c|}
\hline \multirow[t]{2}{*}{ Treatments } & \multicolumn{2}{|c|}{ GSH (ng/gFW) } & \multicolumn{2}{|c|}{ GSSG (ng/gFW) } & \multicolumn{2}{|c|}{ GSH/GSSG } \\
\hline & Root & Leaf & Root & Leaf & Root & Leaf \\
\hline$+\mathrm{Cs}^{+G .}$ mosseae & $112.3 \pm 6.2^{\mathrm{a}}$ & $143 \pm 19^{\mathrm{b}}$ & $29.99 \pm 0.94^{\mathrm{ab}}$ & $75.2 \pm 9.6^{\mathrm{a}}$ & $5.49 \pm 0.90^{\mathrm{a}}$ & $2.02 \pm 0.49^{\mathrm{ab}}$ \\
\hline$+\mathrm{Cs}^{+ \text {G. versiforme }}$ & $125.3 \pm 0.9^{\mathrm{a}}$ & $103 \pm 12^{\mathrm{b}}$ & $20.7 \pm 2.5^{\mathrm{b}}$ & $76.9 \pm 3.4^{\mathrm{a}}$ & $4.04 \pm 0.19^{b}$ & $1.36 \pm 0.22^{\mathrm{b}}$ \\
\hline$+\mathrm{Cs}^{-\mathrm{AM}}$ & $74.1 \pm 4.3^{\mathrm{b}}$ & $234.8 \pm 3.9^{\mathrm{a}}$ & $31.1 \pm 1.6^{\mathrm{a}}$ & $92.7 \pm 8.6^{\mathrm{a}}$ & $2.47 \pm 0.07^{c}$ & $2.58 \pm 0.26^{\mathrm{ab}}$ \\
\hline$-\mathrm{Cs}^{-\mathrm{AM}}$ & $71.4 \pm 8.4^{\mathrm{b}}$ & $258.3 \pm 8.2^{\mathrm{a}}$ & $32.2 \pm 8.1^{\mathrm{a}}$ & $94 \pm 17^{\mathrm{a}}$ & $2.36 \pm 0.27^{\mathrm{c}}$ & $2.96 \pm 0.59^{\mathrm{a}}$ \\
\hline
\end{tabular}

pared to $+\mathrm{Cs}^{-\mathrm{AM}}$ in leaves and roots. In leaves

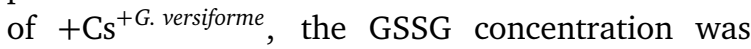
less pronounced with respect to $+\mathrm{Cs}^{-\mathrm{AM}}$, while it was significantly pronounced in roots, the ratio of $\mathrm{GSH} / \mathrm{GSSG}$ in $+\mathrm{Cs}^{+G \text {. mosseae }}$ and $+\mathrm{Cs}^{+G \text {. versiforme }}$ plants was higher than $+\mathrm{Cs}^{-\mathrm{AM}}$, although there was no significant difference among them. However, in roots of $+\mathrm{Cs}^{+G}$. mosseae and $+\mathrm{Cs}^{+G}$. versiforme, GSH/GSSG ratios were 3.37- and 2.23-fold significantly higher than those of $+\mathrm{Cs}^{-\mathrm{AM}}$, respectively. Additionally, there was no significant difference between $+\mathrm{Cs}^{-\mathrm{AM}}$ and $-\mathrm{Cs}^{-\mathrm{AM}}$.

\section{Effects of AMF on enzymes in the ascorbate-glutathione cycle}

Fig. 2 illustrates the effects of $G$. mosseae and $G$. versiforme inoculations on APX activities in leaves and roots of $S$. halepense. In roots of $+\mathrm{Cs}^{+G}$. mosseae and $+\mathrm{Cs}^{+G}$. versiforme plants, the activities of APX significantly increased by 3.5- and 2.09-fold, with respect to $+\mathrm{Cs}^{-\mathrm{AM}}$ plants. The activities of APX in leaves of $+\mathrm{Cs}^{+G}$. versiforme plants were significantly higher than those in leaves of $+\mathrm{Cs}^{-\mathrm{AM}}$ plants, while $+\mathrm{Cs}^{+G}$. mosseae plants had no significant difference compared to $+\mathrm{Cs}^{-\mathrm{AM}}$ plants. There were no significant difference between $+\mathrm{Cs}^{-\mathrm{AM}}$ and $-\mathrm{Cs}^{-\mathrm{AM}}$ plants in roots and leaves.

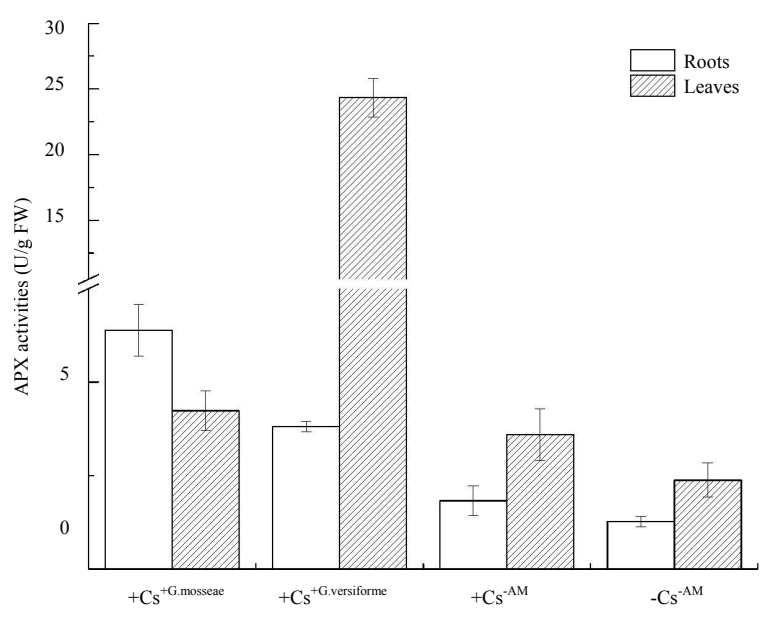

Fig. 2 The effects of arbuscular mycorrhizal fungi (AMF) on ascorbate peroxidase (APX) activities of roots and leaves $+\mathrm{Cs}^{+G \text {. mosseae }},+\mathrm{Cs}^{+G \text {. versiforme }},+\mathrm{Cs}^{-\mathrm{AM}}$, and $-\mathrm{Cs}^{-\mathrm{AM}}$ in $S$. halepense.

The activities of DHAR in leaves and roots of $+\mathrm{Cs}^{+G \text {. mosseae }}$ and $+\mathrm{Cs}^{+G}$. versiforme plants are shown in Fig. 3. It demonstrated that the activities of DHAR in roots of $+\mathrm{Cs}^{+G \text {. mosseae }}$ and $+\mathrm{Cs}^{+G}$. versiforme plants were significantly higher by 3.78-, 2.64fold, respectively, compared to $+\mathrm{Cs}^{-\mathrm{AM}}$ plants. In leaves of $+\mathrm{Cs}^{+G}$. mosseae plants, the activity of DHAR 


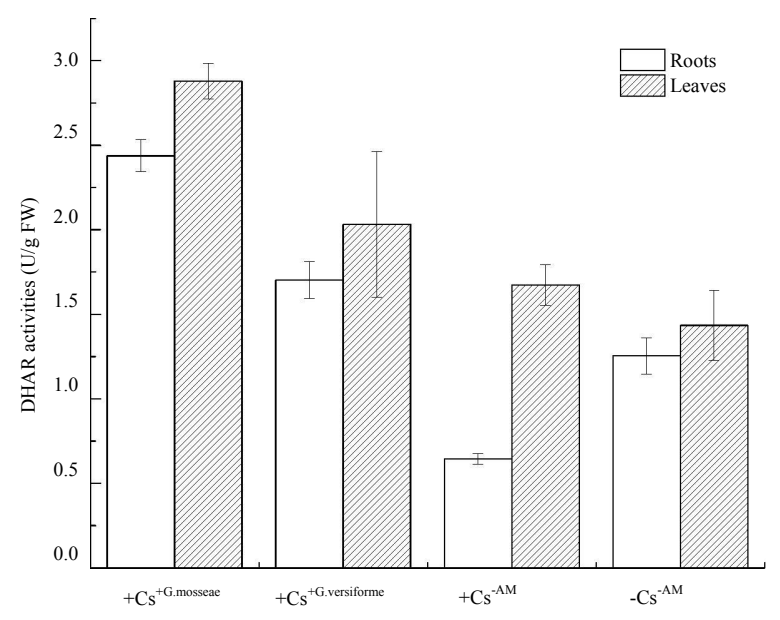

Fig. 3 The effects of arbuscular mycorrhizal fungi (AMF) on dehydroascorbate reductase (DHAR) activities of roots and leaves $+\mathrm{Cs}^{+ \text {G. mosseae }},+\mathrm{Cs}^{+ \text {G. versiforme }},+\mathrm{Cs}^{-\mathrm{AM}}$, and $-\mathrm{Cs}^{-\mathrm{AM}}$ in $S$. halepense.

significantly increased by $1.21 \mathrm{U} / \mathrm{gFW}$, while the

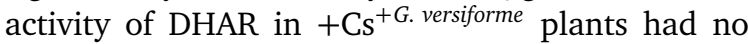
significant difference, compared to that of $+\mathrm{Cs}^{-\mathrm{AM}}$. In roots and leaves of $+\mathrm{Cs}^{-\mathrm{AM}}$ and $-\mathrm{Cs}^{-\mathrm{AM}}$ plants, the activity of DHAR was not significantly different.

The G. mosseae and G. versiforme significantly increased MDHAR activity under caesium stress (Fig. 4). In roots of $+\mathrm{Cs}^{+G \text {. mosseae }}$ and $+\mathrm{Cs}^{+G \text {. versiforme }}$ plants significantly increased by 2.91-, 2.07-fold. There was however no significant difference between leaves of $+\mathrm{Cs}^{+G \text {. mosseae }}$ and $+\mathrm{Cs}^{+G \text {. versiforme }}$ plants relative to $+\mathrm{Cs}^{-\mathrm{AM}}$ plants. Similarly, there was no significant difference between $+\mathrm{Cs}^{-\mathrm{AM}}$ and $-\mathrm{Cs}^{-\mathrm{AM}}$ plants.

The effects of $G$. mosseae and $G$. versiforme on activity of GR in response to caesium stress are shown in Fig. 5. In roots of $+\mathrm{Cs}^{+G \text {. mosseae }}$ plants, the activity of GR was significantly increased by about 2.34-fold, but $+\mathrm{Cs}^{+ \text {G. versiforme }}$ plants had no significant difference compared to $+\mathrm{Cs}^{-\mathrm{AM}}$ plants. On the other hand, in leaves of $+\mathrm{Cs}^{+G \text {. mosseae }}$ and $+\mathrm{Cs}^{+G \text {. versiforme }}$ plants, the activity of GR were less pronounced with respect to $+\mathrm{Cs}^{-\mathrm{AM}}$ plants. In roots and leaves of $+\mathrm{Cs}^{-\mathrm{AM}}$ and $-\mathrm{Cs}^{-\mathrm{AM}}$ plants, the activities of GR had no significant difference.

\section{Effects of AMF on Cs accumulating capacity}

The effects of AMF on the accumulative capacity of $S$. halepense to Cs in roots and leaves are shown in Table 3. It was observed that inoculated with $G$. mosseae and G. versiforme plants significantly increased the concentrations of Cs of plants in leaves

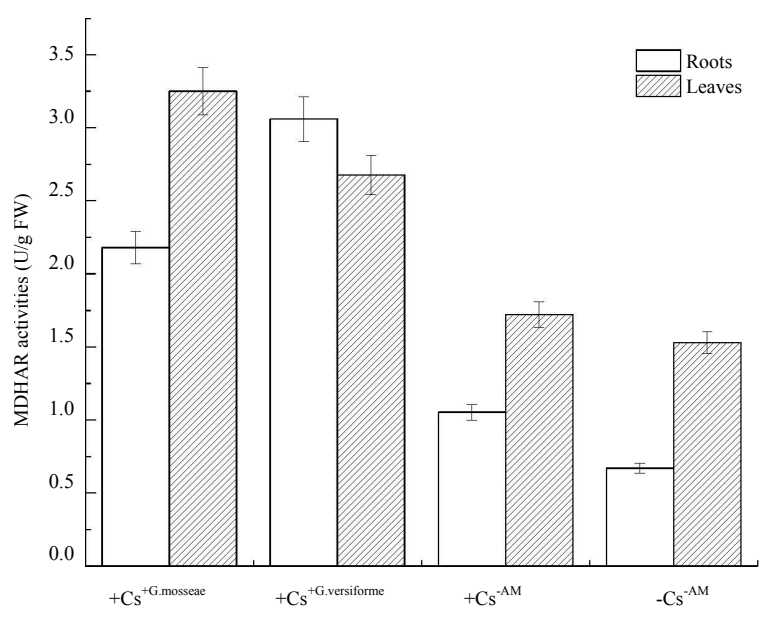

Fig. 4 The effects of arbuscular mycorrhizal fungi (AMF) on monodehydroascorbate reductase (MDHAR) activities of roots and leaves $+\mathrm{Cs}^{+G \text {. mosseae }},+\mathrm{Cs}^{+G \text {. versiforme }},+\mathrm{Cs}^{-\mathrm{AM}}$, and $-\mathrm{Cs}^{-\mathrm{AM}}$ in $S$. halepense.

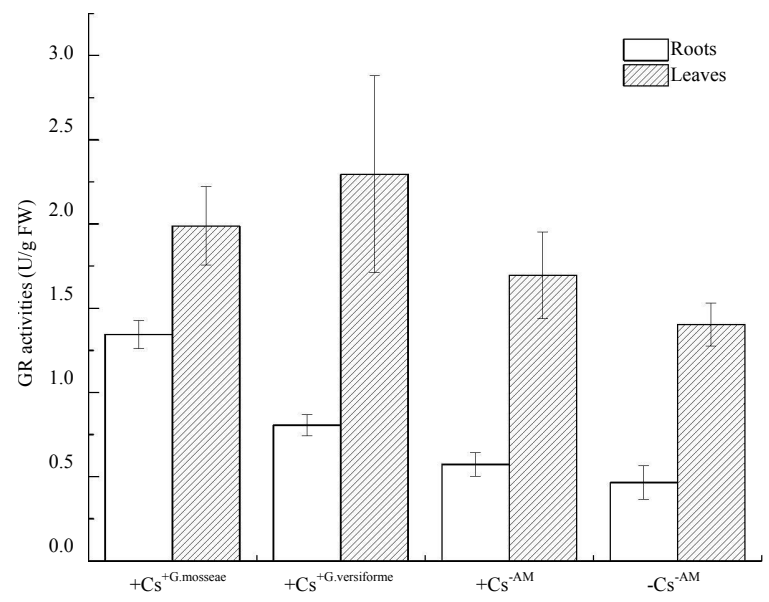

Fig. 5 The effects of arbuscular mycorrhizal fungi (AMF) on glutathione reductase (GR) activities of root and leaves $+\mathrm{Cs}^{+ \text {G. mosseae }},+\mathrm{Cs}^{+ \text {G. versiforme }},+\mathrm{Cs}^{-\mathrm{AM}}$, and $-\mathrm{Cs}^{-\mathrm{AM}}$ in S. halepense.

and roots with respect to $+\mathrm{Cs}^{-\mathrm{AM}}$. Particularly, Cs concentrations of $+\mathrm{Cs}^{+G}$. mosseae plants were significantly higher by 657.72 and $884.39 \mathrm{mg} / \mathrm{kg} \mathrm{DW}$ in roots and leaves, respectively. In $+\mathrm{Cs}^{+ \text {G. versiforme }}$ of plants, Cs concentrations were significantly increased by 170.45 and $328.68 \mathrm{mg} / \mathrm{kg}$ DW. When compared with $+\mathrm{Cs}^{-\mathrm{AM}}$, a significant difference in increase of Cs concentration was found between

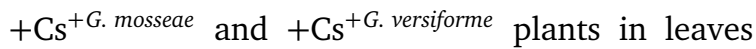
and roots. In soil Cs concentration was significantly lower relative to $+\mathrm{Cs}^{-\mathrm{AM}}$ plants, especially in $+\mathrm{Cs}^{+G}$. mosseae plant was significantly lower than 
Table 3 The effects of different arbuscular mycorrhizal fungi on bioconcentration factor, transfer factor and Cs concentration of roots and leaves in S. halepense and the soil in experimental pot.

\begin{tabular}{|c|c|c|c|c|c|c|}
\hline \multirow[t]{2}{*}{ Treatments } & \multicolumn{3}{|c|}{ Cs concentration(mg/kg DW) } & \multicolumn{2}{|c|}{ Bioconcentration factor } & \multirow{2}{*}{$\begin{array}{c}\text { Transfer } \\
\text { factor }\end{array}$} \\
\hline & Root & Leaf & Soil & Root & Leaf & \\
\hline$+\mathrm{Cs}^{+G .}$ mosseae & $1154 \pm 110^{\mathrm{a}}$ & $1498 \pm 98^{\mathrm{a}}$ & $70.0 \pm 8.5^{c}$ & 16.47 & 21.38 & 1.30 \\
\hline$+\mathrm{Cs}^{+G . \text { versiforme }}$ & $666 \pm 121^{b}$ & $942 \pm 46^{\mathrm{b}}$ & $123 \pm 12^{\mathrm{b}}$ & 5.41 & 7.65 & 1.41 \\
\hline$+\mathrm{Cs}^{-\mathrm{AM}}$ & $496 \pm 48^{c}$ & $613 \pm 52^{c}$ & $146 \pm 10^{\mathrm{a}}$ & 3.40 & 4.21 & 1.24 \\
\hline
\end{tabular}

that of $+\mathrm{Cs}^{+ \text {G. versiforme }}$ plants, only about $48 \%$ of $+\mathrm{Cs}^{-\mathrm{AM}}$. The bioconcentration factor of leaves is higher than those in roots whether mycorrhizal or mycorrhizal plants. It demonstrates that the translocating capacity of $S$. halepense to Cs from roots to leaves is huge, and a large proportion of caesium was enriched in leaves. Additionally, G. mosseae and $G$. versiforme also slightly increased the transfer factor of $S$. halepense to Cs compared to $+\mathrm{Cs}^{-\mathrm{AM}}$ plants; furthermore, the transfer factor of $+\mathrm{Cs}^{-\mathrm{AM}}$ plants reached 1.24 .

\section{DISCUSSION}

A well-developed mycorrhizal symbiosis may enhance the survival of plants in polluted areas by improving water relations, nutrient acquisition, pathogenic resistance, soil structure, phytohormone production, and soil aggregation, thus improving the success of all kinds of bioremediation procedures such as increased caesium uptake by AMF treated plants. These procedures can be used effectively into establish plant coverage on radionuclide contaminated soils to reduce environmental risks ${ }^{10,13}$. Rufyikiri et al demonstrated greater resistance of mycorrhiza banana plantlets grown in vitro to Al toxicity than the nonmycorrhizal plantlets under continuous nutrient flow conditions ${ }^{29}$. Latef et al reported that $G$. mosseae protect tomato against salinity stress by alleviating the salt induced oxidative stress ${ }^{30}$. In this study, it was clearly shown that the ascorbate-glutathione pathway in roots and leaves of $S$. halpense was affected by AMF exposed to Cs stress, but the responses in both plant organs were not similar. It was obvious that the AMF combined with the roots significantly increased the antioxidant substances and the activities of antioxidant enzyme of AsA-GSH cycle, Cs as a signal translocated from roots to the leaves to activate a defence system in the plant cells which can cope with Cs levels.

GSH is reductant to the regeneration of AsA in the AsA-GSH cycle and is used as a potential marker for oxidative changes in plant metabolism.
The concentration of GSH and GSH/GSSG ratio in $+\mathrm{Cs}^{+G \text {. mosseae }}$ and $+\mathrm{Cs}^{+ \text {G. versiforme }}$ plants was significantly higher than those of $+\mathrm{Cs}^{-\mathrm{AM}}$ plants. But, GSSG in AMF-plant roots was lower than that in $+\mathrm{Cs}^{-\mathrm{AM}}$ plant roots, which was partly resulting in the increased activity of $\mathrm{GR}$ of $+\mathrm{Cs}^{+G}$. mosseae and $+\mathrm{Cs}^{+G}$. versiforme to recycle GSSG to GSH, thus increasing the resistance of plants to Cs stress. However, in leaves of $+\mathrm{Cs}^{+G}$. mosseae and $+\mathrm{Cs}^{+G}$. versiforme, the concentrations of GSH and GSH/GSSG ratio were significantly lower than those of $+\mathrm{Cs}^{-\mathrm{AM}}$ plants, and were in accordance with Cuypers et al, who reported changes in the concentration of GSH and GSH/GSSG ratio at $168 \mathrm{~h}$ after exposure to zinc $^{31}$. The studies have demonstrated that AsA is the most abundant antioxidant in plants and exogenous application of AsA increases resistance to chilling, drought $^{21}$, and salt stress ${ }^{22}$. It is obvious that AMF decreases the concentration of DHA of $+\mathrm{Cs}^{+G}$. mosseae and $+\mathrm{Cs}^{+G \text {. versiforme }}$ compared to $+\mathrm{Cs}^{-\mathrm{AM}}$ in roots and leaves, increases the concentration of AsA that improves the resistance of plants. It was shown that the AsA/DHA of group $+\mathrm{Cs}^{+\mathrm{AM}}$ increased significantly compared to that of group $+\mathrm{Cs}^{-\mathrm{AM}}$, resulting from a decrease of DHA but an increase of AsA in groups $+\mathrm{Cs}^{+\mathrm{AM}}$. These results were related to the increase of GSH (Table 3) and the activity of DHAR (Fig. 2), as well as the full reduction of DHA to AsA in groups $+\mathrm{Cs}^{+\mathrm{AM}}$.

The present studies reported that mycorrhization with AMF were able of increasing the resistance of host plants, results in increasing efficient metabolism of ascorbate-glutathione (AsA-GSH) cycle in roots of host plants; hence it would increase the capacities of plants to scavenging reactive oxygen species. De Leonardis demonstrated that increased activities of MDHAR and DHAR oxidized DHA into ascorbate to effectively scavenge toxic oxygen species in potato tuber mitochondria ${ }^{23}$. In roots, the antioxidant substances and the activities of antioxidant enzyme of AsA-GSH cycle were affected by AMF under Cs stress. For instance, the activities of APX, MDHAR, and DHAR of $+\mathrm{Cs}^{+G}$. mosseae 
and $+\mathrm{Cs}^{+ \text {G. versiforme }}$ were significantly higher than those in $+\mathrm{Cs}^{-\mathrm{AM}}$ plants (Figs. 2, 3, 4) and the AsA/DHA ratio significantly increased due to increase of AsA with decrease in DHA compared to $+\mathrm{Cs}^{-\mathrm{AM}}$ plants (Table 1). It suggests that AMF increased concentration of AsA and the activities of APX, MDHAR and DHAR to efficiently promote the operation of AsA-GSH cycle to translocate Cs from roots to leaves, in a certain extent, relieving the toxicity of Cs. Several studies suggested that mycorrhizal symbiosis helps plants to alleviate salt stress and $\mathrm{Cu}$ stress by enhancing the activities of APX, MDHAR, and DHAR ${ }^{32-34}$.

To estimate the benefits of AMF in restoring the soil contaminated with radionuclide, this study takes the Cs concentration, bioconcentration factor and transfer factor of $S$. halepense. Inoculation AMF significantly increased Cs concentration in leaves of $+\mathrm{Cs}^{+ \text {G. mosseae }}$ and $+\mathrm{Cs}^{+G \text {. versiforme }}$ plants by 328.68 , $884.39 \mathrm{mg} / \mathrm{kg}$ DW and 170.45, 657.71 mg/kg DW in roots, respectively, relative to $+\mathrm{Cs}^{-\mathrm{AM}}$ (Table 3 ). It indicates that AMF could enhance the biological immobilization of plants, while contributing to intraradical hyphal network of arbuscular mycorrhizal symbionts participating in taking up and translocate caesium from root to leaf ${ }^{35}$. Vinichuk et al ${ }^{36}$ studied that G. mosseae increased the ${ }^{137} \mathrm{Cs}$ concentration of sunflower in leaves were accordance with this study. On the other hand, the ascorbate acid was affected (Table 1). These results suggest that increased biosynthesis of AsA was a stimulating factor of Cs imposed signal translocated from roots to leaves to activate a defence system in the plant cells which can cope with Cs toxicity. Additionally, the bioconcentration factor and transfer factor of $+\mathrm{Cs}^{+G}$. mosseae and $+\mathrm{Cs}^{+ \text {G. versiforme }}$ plants were higher than one unit. Provided mycorrhiza or not, S. halpense is a potential candidate for the bioremediation of heavy metal stress ${ }^{37}$.

\section{CONCLUSIONS}

Under Cs stress, the plant with G. mosseae or G. versiforme presents higher antioxidants and antioxidant enzymes of AsA-GSH cycle than non-AMF plant. It indicates that AMF could enhance the resistance of plants to adapt to Cs stress. Meanwhile, AMF promotes Cs enriching in leaves and roots of $S$. halepense, increasing the bioconcentration factor and transfer factor, and decreasing Cs concentration in the soil. Intraradical hyphal network of arbuscular mycorrhizal symbionts are thus useful to promote the removal of Cs from soils to roots.
Acknowledgements: This work was supported by projects from SWUST prep-research fund (15yyhk13, 14tdgc01) and NSCF (31000259), China. We would like to thank Dr Wang of Hua Zhong Agricultural University for the arbuscular mycorrhizal fungi and Prof. Liu of Nanjing Agricultural University for $S$. halepense seeds.

\section{REFERENCES}

1. Strebl F, Gerzabek MH, Bossew P, Kienzl K (1999) Distribution of radiocaesium in an Austrian forest stand. Sci Total Environ 226, 75-83.

2. McGee EJ, Synnott HJ, Johansson KJ, Fawaris BH, Nielsen SP, Horrill AD, Kennedy VH, Barbayiannis N, et al (2000) Chernobyl fallout in a Swedish spruce forest ecosystem. $J$ Environ Radioact 48, 59-78.

3. Rafferty B, Brennan M, Dawson D, Dowding D (2000) Mechanisms of ${ }^{137} \mathrm{Cs}$ migration in coniferous forest soils. J Environ Radioact 48, 131-43.

4. Coughtrey PJ, Jackson D, Jones CH, Kane P, Thorne MC (1984) Radionuclide Distribution and Transport in Terrestrial and Aquatic Ecosystems: A Critical Review of Data, vol 1, AA Balkema, Rotterdam.

5. Howard BJ, Beresford NA, Hove K (1991) Transfer of radiocaesium to ruminants in natural and semi-natural ecosystems and appropriate countermeasures. Health Phys 61, 715-25.

6. Robison WL, Stone EL (1992) The effect of potassium on the uptake of ${ }^{137} \mathrm{Cs}$ in food crops grown on coral soils: coconut at Bikini Atoll. Health Phys 62, 496-511.

7. Camps M, Rigol A, Vidal M, Rauret G (2003) Assessment of the suitability of soil amendments to reduce ${ }^{137} \mathrm{Cs}$ and ${ }^{90} \mathrm{Sr}$ root uptake in meadows. Environ Sci Tech 37, 2820-8.

8. Catsiki VA, Florou H (2006) Study on the behavior of the heavy metals $\mathrm{Cu}, \mathrm{Cr}, \mathrm{Ni}, \mathrm{Zn}, \mathrm{Fe}, \mathrm{Mn}$ and ${ }^{137} \mathrm{Cs}$ in an estuarine ecosystem using Mytilus galloprovincialis as a bioindicator species: the case of Thermaikos gulf, Greece. J Environ Radioact 86, 31-44.

9. Entry JA, Vance NC, Hamilton MA, Zabowski D, Watrud LS, Adriano DC (1996) Phytoremediation of soil contaminated with low concentrations of radionuclides. Water Air Soil Pollut 88, 167-76.

10. Berreck M, Haselwandter K (2001) Effect of the arbuscular mycorrhizal symbiosis upon uptake of cesium and other cations by plants. Mycorrhiza 10, 275-80.

11. Gadd GM (1992) Heavy metal pollutants: environmental and biotechnological aspects. In: Lederberg J (ed) Encyclopedia of Microbiology, vol 2, Academic Press, pp 351-60.

12. Dushenkov S (2003) Trends in phytoremediation of radionuclides. Plant Soil 249, 167-75.

13. de Boulois HD, Delvaux B, Declerck S (2005) Effects of arbuscular mycorrhizal fungi on the root uptake 
and translocation of radiocaesium. Environ Pollut 134, 515-24.

14. Smith SE, Read DJ (2008) Mycorrhizal Symbiosis, 3rd edn, Academic Press, San Diego, CA.

15. Watling R (2006) The sclerodermatoid fungi. Mycoscience 47, 18-24.

16. Harrison MJ (1997) The arbuscular mycorrhizal symbiosis: an underground association. Trends Plant Sci 2, 54-60.

17. Hernández-Ortega HA, Alarcón A, Ferrera-Cerrato R, Zavaleta-Mancera HA, López-Delgado HA, MendozaLópez MR (2012) Arbuscular mycorrhizal fungi on growth, nutrient status, and total antioxidant activity of Melilotus albus during phytoremediation of a diesel contaminated substrate. J Environ Manag 95, 319-24.

18. Declerck S, de Boulois HD, Bivort C, Delvaux B (2003) Extraradical mycelium of the arbuscular mycorrhizal fungus Glomus lamellosum can take up, accumulate and translocate radiocaesium under rootorgan culture conditions. Environ Microbiol 5, 510-6.

19. de Boulois HD, Joner EJ, Leyval C, Jakobsen I, Chen BD, Roos P, Thiry Y, Rufyikiri G, et al (2008) Role and influence of mycorrhizal fungi on radiocesium accumulation by plants. $J$ Environ Radioact $99,785-800$.

20. Chen BD, Zhu YG, Smith FA (2006) Effects of arbuscular mycorrhizal inoculation on uranium and arsenic accumulation by Chinese brake fern (Pteris vittata L.) from a uranium mining-impacted soil. Chemosphere 62, 1464-73.

21. Guo Z, Tan H, Zhu Z, Lu S, Zhou B (2005) Effect of intermediates on ascorbic acid and oxalate biosynthesis of rice and in relation to its stress resistance. Plant Physiol Biochem 43, 955-62.

22. Shalata A, Neumann PM (2001) Exogenous ascorbic acid (vitamin C) increases resistance to salt stress and reduces lipid peroxidation. $J$ Exp Bot 52, 2207-11.

23. de Leonardis S, de Lorenzo G, Borraccino G, Dipierro $S$ (1995) A specific ascorbate free radical reductase isozyme participates in the regeneration of ascorbate for scavenging toxic oxygen species in potato tuber mitochondria. Plant Physiol 109, 847-51.

24. Wang JL, Zeng Q, Zhu JG, Liu G, Tang HY (2013) Dissimilarity of ascorbate-glutathione (AsA-GSH) cycle mechanism in two rice (Oryza sativa L.) cultivars under experimental free-air ozone exposure. Agr Ecosyst Environ 165, 39-49.

25. Phillips JM, Hayman DS (1970) Improved procedures for clearing roots and staining parasitic and vesicular-arbuscular mycorrhizal fungi for rapid assessment of infection. Trans Br Mycol Soc 55, 158-61.

26. Chen JX, Wang XF (2002) Experimental Instruction of Plant Physiology, South China Universigy of Technology Press, Guangzhou, pp 125-7, [in Chinese].

27. Castillo FJ, Greppin H (1988) Extracellular ascorbic acid and enzyme activities related to ascorbic acid metabolism in Sedum album L. leaves after ozone exposure. Environ Exp Bot 28, 232-3.

28. Krivosheeva A, Tao DL, Ottander C, Wingsle G, Dube SL, Öquist G (1996) Cold acclimation and photoinhibition of photosynthesis in Scots pine. Planta 200, 296-305.

29. Rufyikiri G, Declerck S, Dufey JE, Delvaux B (2000) Arbuscular mycorrhizal fungi might alleviate aluminium toxicity in banana plants. New Phytol 148, 343-52.

30. Abdel Latef AAH, He CX (2011) Effect of arbuscular mycorrhizal fungi on growth, mineral nutrition, antioxidant enzymes activity and fruit yield of tomato grown under salinity stress. Sci Hort 127, 228-33.

31. Cuypers A, Vangronsveld J, Clijsters H (2001) The redox status of plant cells (AsA and GSH) is sensitive to zinc imposed oxidative stress in roots and primary leaves of Phaseolus vulgaris. Plant Physiol Biochem 39, 657-64.

32. Abdel Latef AA (2013) Growth and some physiological activities of pepper (Capsicum annuum L.) in response to cadmium stress and mycorrhizal symbiosis. J Agr Sci Tech 15, 1437-48.

33. Evelin H, Kapoor R (2014) Arbuscular mycorrhizal symbiosis modulates antioxidant response in saltstressed Trigonella foenum-graecum. Mycorrhiza 24, 197-203.

34. Meier S, Azcón R, Cartes P, Borie F, Cornejo P (2011) Alleviation of $\mathrm{Cu}$ toxicity in Oenothera picensis by copper-adapted arbuscular mycorrhizal fungi and treated agrowaste residue. Appl Soil Ecol 48, 117-24.

35. Rufyikiri G, Declerck S, Thiry Y (2004) Comparison of ${ }^{233} \mathrm{U}$ and ${ }^{33} \mathrm{P}$ uptake and translocation by the arbuscular mycorrhizal fungus Glomus intraradices in root organ culture conditions. Mycorrhiza 14, 203-7.

36. Vinichuk M, Mårtensson $A$, Ericsson $T$, Rosén $K$ (2013) Effect of arbuscular mycorrhizal (AM) fungi on ${ }^{137} \mathrm{Cs}$ uptake by plants grown on different soils. $J$ Environ Radioact 115, 151-6.

37. Sun YB, Zhou QX, Liu WT, An J, Xu ZQ, Wang L (2009) Joint effects of arsenic and cadmium on plant growth and metal bioaccumulation: a potential Cdhyperaccumulator and As-excluder Bidens pilosa L. J Hazard Mater 165, 1023-8. 